\title{
White Adipose Tissue
}

National Cancer Institute

\section{Source}

National Cancer Institute. White Adipose Tissue. NCI Thesaurus. Code C33889.

Adipose tissue that collects, stores and releases fat in the form of triglycerides. It

functions as a heat insulator, mechanical cushion and as a source of energy. White adipose tissue is composed of adipocytes that secrete leptin and other substances that effect energy homeostasis. Its distribution in the body is dependent on the sex of the individual. 